\title{
CAPM Vs Fama-French Three-Factor Model: An Evaluation of Effectiveness in Explaining Excess Return in Dhaka Stock Exchange
}

\author{
Mahnoor Sattar ${ }^{1}$ \\ ${ }^{1}$ Department of Business Administration, East West University, Bangladesh \\ Correspondence: Mahnoor Sattar, Department of Business Administration, East West University, \\ Bangladesh. E-mail: mahnoor_sattar@live.com
}

Received: February 26, 2017

doi:10.5539/ijbm.v12n5p119
Accepted: March 28, $2017 \quad$ Online Published: April 27, 2017

URL: https://doi.org/10.5539/ijbm.v12n5p119

\begin{abstract}
CAPM has been prevalently used by practitioners for calculating required rate of return despite having drawbacks. Fama French presented their 3 factor model in order to gap the limitations posed by CAPM model. This paper attempts to examine practical implications and effectiveness of Fama French model vis-a-vis the CAPM model in explaining excess return of Dhaka Stock Exchange by analyzing five publicly listed firms of Cement industry over 10 years period of 2004-2014. As the representative of market index, DGEN is taken from 2004 till 2013 and later on DSEX is taken. Simple and multiple linear regression analysis have been used against daily market return and respective companies return. Results shows that adjusted $\mathrm{R}$ square of Fama French model have a higher value than adjusted $\mathrm{R}$ square of CAPM model after running cross sectional regression of the observed panel data. It means that Fama French model is better predicting variation in excess return over $\mathrm{R}_{\mathrm{f}}$ than CAPM for all the five companies of the Cement industry over the period of ten years. Low $p$ values indicate that the coefficients are statistically significant. Nonetheless this paper concludes that the companies who want to use Fama French model instead of CAPM must evaluate the time and effort required to use the model before they replace CAPM with the multi factor model for their stock return analysis.
\end{abstract}

Keywords: CAPM, Fama-French three factor model, excess return, Dhaka stock exchange

\section{Introduction}

After the famous Portfolio Theory of Markowitz, many researchers have come up with different theories aiming to explain excess portfolio returns. One of the ground breaking models is the CAPM which was established by Sharpe (1964) and Lintner (1965) which is still used prevalently in order to calculate cost of equity and determine asset pricing. This seminal theory is based on only one risk factor which is systematic risk. Striking simplicity and the ease of calculation made this theory widely popular among both academicians and practitioners alike. Although CAPM has revolutionized the field of finance but various empirical tests have challenged this theory and revealed several drawbacks. On the other hand, Fama and French three factor model was developed as a response to inadequate performance of the CAPM. The authors argue that anomalies related to the CAPM are better captured by their three factor model. (Fama \& French, Common risk factors in the returns on stocks and bonds, 1993) Although Fama French has tried to overcome the drawbacks of the CAPM but their original three factor model also possess some limitations as well.

The merit of both the theories have been numerously challenged to ascertain their performance in various research papers. Nonetheless, most of the research is conducted on developed markets whereas developing market like Bangladesh remained less explored. Many times it has been found that the developing markets behave quite differently than their developed and efficient counterparts. Few researches have been conducted in light of shares listed in Dhaka Stock Exchange which is been the primary stock exchange in Bangladesh. This paper aims to test both theories by applying it in the context of publicly listed cement companies stock in Bangladesh to evaluate performance of the theories in explaining excess return over risk free return. This research will be conducive for practitioners in selecting model for calculating required return.

\section{Literature review}

\subsection{The Concept of CAPM}

Capital Asset Pricing Model or in short CAPM has its roots on the influential portfolio theory of Markowitz where 
portfolio risk is calculated using mean variance of the associated returns and investors wants to maximize return given a certain risk or minimize risk given a certain return. CAPM is used in the pricing risky securities which explain the relationship between risk and expected return in a linear manner. (Black, Jensen, \& Scholes, 1972) According to the CAPM equation, a linear relationship exists between required return of a stock and its systematic risk known as beta. This single factor systematic risk is innately simple to interpret and is the central piece of this austere model. In equilibrium market risk premiums are depended on respective asset's beta. To reiterate, risk averse investors require a premium over risk free rate in order to be compensated with the additional risk of the asset whereas this premium is associated with beta. The equation of CAPM is given below:

$$
\text { "E }(\mathrm{Ri})=\mathrm{Rf}+\beta(\mathrm{E}(\mathrm{Rm})-\mathrm{Rf}) "
$$

In this equation the variables have following meaning:

$\mathrm{E}(\mathrm{Ri})=$ Expected Return from instrument $\mathrm{i}$

$\mathrm{Rf}=$ Rate of risk free instrument such as government securities

$\mathrm{Rm}=$ average market return usually taken from market proxies

$\mathrm{B}=\operatorname{Cov}(\mathrm{Ri}, \mathrm{Rm}) / \partial \mathrm{m}^{\wedge} 2=$ systematic risk

\subsection{Empirical Test on CAPM}

Plethora of literature is available on CAPM as this is one of the cornerstone theories of finance. it has been tested empirically numerous times where it has been both lauded and critiqued. Both cross section and time series analysis is prevalent in CAPM testing. However, the traditional cross sectional regression does not provide meaningful results as the residuals are correlated. The following regression equation with mean of stock's excess return against market excess return was suggested by Fama and Macbeth in order to overcome this independence of residuals: (FAMA \& MacBeth, 1973)

$$
\mathrm{Ri}-\mathrm{Rf}=\gamma_{0}+\gamma_{\mathrm{i}} \beta_{\mathrm{i}}+\mathrm{e}_{\mathrm{i}}
$$

Empirical evidence shows that poor quality of proxy of the market portfolio can significantly undermine the performance of CAPM model. (Gibbons, Ross, \& Shanken, 1989) Moreover, Fama and French's research shows that although the relationship of return and beta is almost linear, the actual line is more flat than the one predicted by CAPM. This is mainly due to the effects of other factors like size, earnings to price, book to market and debt to equity which are not explained by only systematic risk factor alone. (Fama \& French, The Capital Asset Pricing Model: Theory and Evidence, 2004) Moreover, CAPM does not account for time variant factors in calculating an asset's risk in cross sectional and time variant data. (Lettau \& Ludvigson, 2001) Many authors have come to extended version of this model like conditional CAPM to overcome original model's limitations. Nonetheless, Graham and Harvey conducted a comprehensive research and find that $73.5 \%$ among 392 American CFOs depend on this theory to find the cost of equity. (Graham \& Harvey, 2001) Moreover, Brounen, Jong and Koedijk performed a similar studying 2004 with 313 European companies where they found that almost $45 \%$ companies relies on CAPM. (Brounen, Abe de Jong, \& Koedijk, 2004)

Quite a few empirical tests including Black, Jensen and Scholes (1972) and Fama and Mac Beth (1973) overall support the CAPM. Nonetheless, several deviations from the CAPM were found in1980s \& 1990s which raised many questions about the theory. In a research Basu explains that stocks with high E/P have more future return than those predicted by the CAPM (Basu, 1977). Moreover, researcher Banz documents low market to book value stocks earned a higher than projected return which is not explained by capm theory. (Banz, 1981) Even though small cap stocks have higher betas and higher typical returns than big cap stocks but the gap in returns is greater than CAPM's predictions. Furthermore, Bhandari demonstrates leverage has positive correlation with expected stock returns. (BHANDARI, 1988)

\subsection{Fama-French Three-Factor Model}

Fama and French proposed a new model with 3 factors to better explain cross sectional expected returns. They observed that small in terms of market capitalization and value stocks with Low P/B perform superior than the overall market. (Fama \& French, 1993) Therefore they added two additional factors to CAPM equation:

$$
\mathrm{E}(\mathrm{Ri})=\mathrm{Rf}+\beta(\mathrm{E}(\mathrm{Rm})-\mathrm{Rf})+\beta \mathrm{SMB}(\mathrm{RSMALL}-\mathrm{RBIG})+\beta \mathrm{HML}(\mathrm{RHBM}-\mathrm{RLBM})
$$

Here $\mathrm{E}(\mathrm{Ri}), \mathrm{Rf}$ and $\mathrm{Rm}$ stands for portfolio's expected return, risk-free return rate and market return respectively. SMB is the value of Small market cap minus Big and HML is High book value to market ratio minus Low. In the long run, small stocks have found to generate higher returns than large stocks whereas value stocks have generated higher returns than growth stocks although they contain more risk. 


\subsection{Empirical Tests and Recent Development of Fama French Five Factor Model}

Empirical tests on various stock market represents the superiority of explanatory power of Fama French model. Nonetheless, heterogeneous results can also be found as portfolio selection plays a crucial role in this. (Blanco, 2012) After publishing their ground breaking three factor model Fama and French continued their research to even better explain the expected return of the stock.in their recent paper they have mentioned five dominant factors contributing to a stocks expected return. They are size, value, profitability, and investment patterns. Companies with higher future earnings will have higher stock market returns. They have found that these factors combined has better predictability power of stock's return than the previous three factor model. (Fama \& French, A Five-Factor Asset Pricing Model, 2015)

\subsection{Research Rational}

The stock market plays a pivotal role in any country's industrialization. Albeit there are many research done on the effectiveness of CAPM and Fama French theories in developed countries' stock exchange, study on the stock market of Bangladesh are not prevalent. Depending on market characteristics and investor behavior same theory might work well in develop market but not in developing one. Even though Bangladesh has many impediments like political turbulence, natural calamity and underdeveloped infrastructure, it still successfully achieved on average 6\% GDP growth every year. These characters make Bangladesh a prototype emerging economy for academics to study which can be later applicable to many other emerging economies like Vietnam, India, Pakistan and even China.

The history of capital market in Bangladesh dates before independence in 1954. (Introduction to DSE, n.d.)Since its inception, Dhaka Stock exchange has been expanding rapidly to be congruent with the need of growing economy of Bangladesh. Nevertheless, the Dhaka stock market did not get enough attention from the researchers. Although plethora of literature can be found on CAPM test done on developed market, practically negligible amount exists in the context of Bangladesh. Based on a data set of non-financial companies over the period of 1999-2003 Rahman et. al find that Fama French model has better explanatory power notwithstanding the market inefficiency in DSE. (Rahman, Baten, Uddin, \& Zubayer, 2006)

Dearth of existing literature on this issue in the context of DSE arises the need to explore the matter further. For this study of evaluating excess return, analyzing all the stocks listed in DSE is the idealistic scenario. Nevertheless, it is both time consuming and lengthy to do. Meanwhile Bangladesh cement industry has been maintaining a stable growth which is fueled by constant urbanization and construction of infrastructure. According to a research report prepared by investment bank IDLC, cement market in Bangladesh is nearly 1.74 billion USD and the capacity to produce is about 25 million metric ton. This sector has been experiencing a stable growth over the past years and expected to maintain such attribute. (Nayan, 2013) Given the resources constraints, cement industry is a suitable pick for this research. Moreover, this research will help practitioners to pick a feasible method to find out stock's expected return.

\section{Industry Overview}

The cement industry in Bangladesh has a vibrant footstep in the booming economy. It is growing in proportion to the need of growing urbanization in the country. Before 1994, the total demand of cement in Bangladesh was entirely met by imported cements. But after that this industry has never looked back. The cement industry is now $40^{\text {th }}$ biggest cement market in global ranking. Cement industry in Bangladesh faces a seasonal effect as the sales become peak in September to May and declines afterwards. (Hossain, 2015) Although the market contains many players but few of them dominates this sector. The listed company's sector wise contribution in the sector capitalization during 2015 (average of January till December 2015) is given below: 


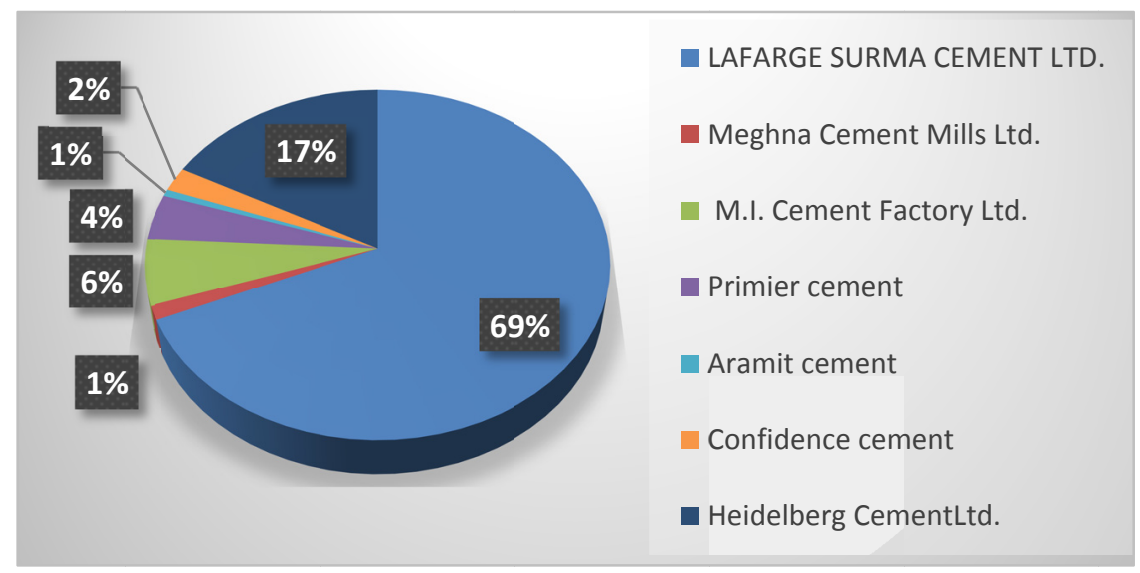

Figure 1. Company wise contribution in Cement sector capitalization

Source: Pie chart was constructed by author based on data collected from Dhaka Stock Exchange

It is fair to say that the bargaining power of the buyers in this sector is fairly low as it is dominated by these players. Moreover, the growing construction work of various infrastructure projects including the Padma Bridge is a great scope for the industry to grow further.

\section{Research Questions}

The research questions are as follows:

- To study the impact of CAPM and Fama-French three factor model on the return of listed cement industry companies of Bangladesh.

- To look into the effectiveness of the theories and practices in real world scenario.

\section{Methodology}

This paper is strictly quantitative in nature and uses conventional statistical tools such as simple and multiple linear regression analysis. Data is collected mostly from Dhaka Stock Exchange (DSE) and it is analyzed with the help of Microsoft Excel software. Both single factor (CAPM) and multi factor (Fama-French) models were applied via regression to find out the effectiveness of the models in comparison to each other. Total 2663 observations were taken into consideration to make the research meaningful and reliable. Simple linear regression is used for CAPM and multiple variable regression is used for Fama French model on the balanced pooled data. Adjusted $\mathrm{R}^{2}$ is considered as a validity of the regression output. Low $\mathrm{p}$ value means the study is statistically significant. The time frame of the dataset is 10 years which will reduce any short term anomalies like stock market crash of 2010-11.

\subsection{Assumptions of the Study}

As this is a quantitative paper and five listed cement company's price data were adjusted and used in a regression model. This study has the following assumptions:

- It is assumed that the market index is a reasonable representative of the market portfolio.

- Since Face value of the companies changed from tk 100 to tk 10 previous market prices were divided by 10 and the number of shares were multipliedby 10 to make the analysis consistent. The price adjusting effect is similar to a 10:1 stock split.

- It is assumed that 2014 market capitalization wise order and 2014 Book to Market value wise order of the companies were constant throughout the observed period.

\subsection{Companies Analyzed}

Out of 7 companies listed under cement industry in Dhaka Stock Exchange, this research has taken 5 companies namely Aramit Cement, Confidence Cement, Heidelberg Cement, Lafarge Surma Cement \& Meghna Cement are considered for the analysis due to availability of trade data for the period 2004-2014. The rest two companies namely MI Cement and Premier Cement are excluded due to consistency of the calculations since they got listed in the stock exchange in 2011 and 2013 respectively. 


\subsection{Market Portfolio Proxy}

From 2004-2013 the market index DGEN (Dhaka Stock Exchange General Index) was used as a proxy for market return. However, On January 28, 2013, DSE introduced DSE Broad Index (DSEX) as a market index which was developed by the method of Standard and Poor's. This free floating market index is believed to be a more precise estimate of the market portfolio. (Ahmed, 2013) Therefore, DGEN is taken from 2004 till 2013 and later on DSEX is taken as the representative of market index.

\subsection{Size and Value Premium for Companies}

The five shares of cement industry have been ranked according to their market capitalization for size and according to their Book value to market value for their value premium. For simplicity the figures and ranking of December 30, 2014 is assumed to be constant throughout the studied period.

Table 1: Small vs Big and High vs Low position calculation

\begin{tabular}{llllllll}
\hline Company Name & Price & Shares in million & Market Cap in million & SIZE & NAV per share & $\begin{array}{l}\text { NAV/price } \\
\text { =Book to Mkt Value }\end{array}$ & $\begin{array}{l}\text { VALUE } \\
\text { Lafarge Surma }\end{array}$ \\
\hline & 123 & 14000 & 1722000 & Big & 11.41 & 0.09 & low \\
Heidelberg & 499.4 & 1000 & 499400 & & 115.46 & 0.23 & low \\
Confidence & 106.7 & 1000 & 106700 & Small & 64.41 & 0.60 & high \\
Meghna & 121.1 & 5000 & 605500 & Big & 36.1 & 0.30 & \\
Aramit & 39.0 & 500 & 19500 & Small & 15.49 & 0.40 & high \\
\hline
\end{tabular}

Note. Market Capitalization as at 30 December, 2014.

\subsection{Risk Free Rate}

Five year T-bond of Bangladesh government issued in December 2014 with annualized interest rate of $9.6 \%$ is considered to be relevant risk free rate $\left(\mathrm{R}_{\mathrm{f}}\right)$.

\subsection{Return Calculation}

Daily return was calculated for the observed period of ten years. Only the capital gain was considered for the calculation. No price adjustment was made for cash or stock dividends. Excess return was calculated by subtracting risk free rate from individual stock's return.

\subsection{Confidence Level}

Excess return of each stock was used to run regression against market excess return for CAPM and against market risk premium, size and value premium for fama French model. Regression analysis was done with 95\% confidence level meaning alpha (Level of significance) was $5 \%$.

\section{Findings and Recommendations}

Daily excess return i.e. Aramit's return minus risk free rate over the period of 10 years of each of the five stocks have used to run regression against market risk premium for CAPM. On the other hand, daily excess return is used to run multiple linear regression against all three factors of fama French such as market risk premium, size (Small minus Big) and value (High minus Low) premium. After running single and multiple linear regression following result was found:

Table 2. CAPM linear regression results

\begin{tabular}{llllll}
\hline Company Name & R square & Adjusted R square & beta & t-values & p-value \\
\hline Aramit & $13.12 \%$ & $13.08 \%$ & 0.88 & 18.17 & 0.00 \\
Confidence & $34.30 \%$ & $34.27 \%$ & 1.08 & 33.79 & 0.00 \\
Heidelberg & $27.02 \%$ & $26.98 \%$ & 0.77 & 28.45 & 0.00 \\
Lafarge surma & $29.29 \%$ & $29.26 \%$ & 0.90 & 30.09 & 0.00 \\
Meghna & $30.36 \%$ & $30.33 \%$ & 1.07 & 30.87 & 0.00 \\
\hline
\end{tabular}

Note: Regression conducted at 95\% confidence level 
Table 3. Fama-French 3 factor multiple linear regression results

\begin{tabular}{llllllll}
\hline & R square & Adjusted R square & Rm-Rf & SMB & HML & t-values & p-value \\
\hline Aramit & $70.64 \%$ & $70.60 \%$ & 0.79 & 0.77 & -0.65 & -31.50 & 0.00 \\
Confidence & $53.23 \%$ & $53.17 \%$ & 1.01 & 0.36 & 0.55 & 27.68 & 0.00 \\
Heidelberg & $36.64 \%$ & $36.55 \%$ & 0.77 & -0.12 & 0.24 & 12.89 & 0.00 \\
Lafarge surma & $61.80 \%$ & $61.75 \%$ & 0.99 & -0.53 & -0.56 & -34.53 & 0.00 \\
Meghna & $52.42 \%$ & $52.36 \%$ & 0.98 & 0.59 & 0.33 & 15.61 & 0.00 \\
\hline
\end{tabular}

Note. Regression conducted at $95 \%$ confidence level.

The regression results from the above mentioned table indicates that Fama-French model can better explain the variability in the stock return for companies in the cement industry than that by CAPM model. This is evident from the comparisons of adjusted $\mathrm{R}$ squared values which improves significantly for each company when Fama French model is used instead of CAPM. The beta for market index goes down for each stock except for Lafarge surma when Fama French model is used. It implies that there are many variables that can explain variability in stock return other than market portfolio which is captured by Fama French model. The overall positive coefficients of the Small minus big column suggests that small firms tend to have higher return which is congruent to the fact that they are more risky in general than their larger counterparts. Similarly, three out of five coefficients in the High minus Low column are positive indicating higher return for High book to market value firms. On the other hand, Low $\mathrm{p}$ value of the regression implies that the study is statistically significant. Moreover, a long term period of 10 years' data might diminish market anomalies in the short term to increase the reliability of this results.

The Findings and recommendations of this study is summarized below:

- The systematic risk factor alone has less explanatory power in explaining the excess return whereas including size and value beta increases the adjusted $\mathrm{R}$ squared values in the regression model of cross sectional time series data.

- Fama-French 3 factor model is better predicting the excess return over Risk free rate than CAPM for all the five companies of the Cement industry over the period of 2004-2014. This is congruent with the theoretical model of Fama French.

- Executing Fama French model is more cumbersome and time consuming which might not be time and cost effective for the practitioners.

\section{Conclusion}

In this paper, both CAPM and Fama French three factors model have been applied in explaining return of cement industry of Bangladesh over a period of ten years. The results are congruent with the Fama French theory suggesting more explanatory power of the model over the CAPM one as beta alone can not predict much of the variation in cross section return. Nevertheless, this model is much more complex than CAPM and it takes more time to compute as well. Practitioners may not find it cost effective to collect the additional information required by the three-factor model. In the context of Dhaka Stock Exchange, most individual investors lack in depth financial knowledge and prefers simpler methods in determining required return. However, institutional practitioners who want to use Fama French model instead of CAPM must evaluate the time and effort required to use the model before they replace CAPM with the multi factor model for their stock return analysis.

Only the Cement Industry of Bangladesh is analyzed with CAPM and Fama-French three factor model. Moreover, incorporating multiple industry data in comparing the effectiveness of these models is out of scope for this paper. This can create window of opportunity for future research in determining suitable method for institutional investors of Bangladesh.

\section{Reference}

Ahmed, G. T. (2013). DSE launches two indices for better calculation. Retrieved from $\mathrm{http}: / / \mathrm{www}$.thedailystar.net/news-detail-266952

Banz, R. W. (1981). The Relationship between Return And Market Value. Journal of Financial Economics, 3-18. https://doi.org/10.1016/0304-405X(81)90018-0

Basu, S. (1977). Investment Performance of Common Stocks in Relation to their Price-Earnings Rations: A Test of the Efficient Market Hypothesis. The Journal of Finance, 663-682. 
https://doi.org/10.1111/j.1540-6261.1977.tb01979.x

Bhandari, L. C. (1988). Debt/Equity Ratio and Expected Common Stock Returns: Empirical Evidence. The Journal of Finance, 507-528. https://doi.org/10.1111/j.1540-6261.1988.tb03952.x

Black, F., Jensen, M. C., \& Scholes, M. (1972). The Capital Asset Pricing Model: Some Empirical Tests. NewYork: Praeger Publishers Inc.

Black, F., Jensen, M., \& Scholes, M. (1972). The Capital Asset Pricing Model: Some Empirical Tests. In M. Jensen (Ed.), Studies in the theory of capital markets.

Blanco, B. (2012). The use of CAPM and Fama French Three factor model: portfolios selection. Public and Municipal Finance, 1(2).

Brounen, D., Abe, D. J., \& Koedijk, K. (2004). Corporate Finance in Europe Confronting Theory with Practice. Financial Management, 33, 71-101. https://doi.org/10.2139/ssrn.559415

Fama, E. F., \& French, K. R. (1993). Common risk factors in the returns on stocks and bonds. Journal of Financial Economics, 3-56. https://doi.org/10.1257/0895330042162430

Fama, E. F., \& French, K. R. (2004). The Capital Asset Pricing Model: Theory and Evidence. Journal of Economic Perspectives, 18, 25-46. https://doi.org/10.1016/j.jineco.2014.10.010

Fama, E. F., \& French, K. R. (2015). A Five-Factor Asset Pricing Model. Journal of Financial Economics.

FAMA, E. F., \& MacBeth, J. D. (1973). Risk, Return, and Equilibrium: Empirical Tests. The Journal of Political Economy, 81(3), 607-636. https://doi.org/10.1086/260061

Fama, E., \& French, K. (1996). Multifactor Explanations of Asset. Journal of Finance, 51, 55-84. https://doi.org/10.1111/j.1540-6261.1996.tb05202.x

Fama, E., \& MacBeth, J. (1973). Risk, Return and Equilibrium: Empirical Tests. Journal of Political Economy, 81, 607-636. https://doi.org/10.1086/260061

Gibbons, M. R., Ross, S. A., \& Shanken, J. (1989). A Test of the Efficiency of a Given Portfolio. Econometrica, 57(5), 1121-1152. https://doi.org/10.2307/1913625

Graham, J. R., \& Harvey, C. R. (2001). The theory and practice of corporate finance: Evidence from the field. Journal of Financial Economics. https://doi.org/10.1016/S0304-405X(01)00044-7

Hossain, M. Y. (2015). Bangladesh's Cement Industry: Thriving After Years of Restructuring. Business Review, $11(3)$.

Introduction to DSE. (n.d.). Retrieved 2016, from Dhaka Stock Exchange: http://www.dsebd.org/ilf.php

Lettau, M., \& Ludvigson, S. (2001). Resurrecting the (C)CAPM: A Cross-Sectional Test When Risk Premia Are Time-Varying. Journal of Political Economy, 109(6). https://doi.org/10.1086/323282

Litner, J. (1965). The Valuation of Risk Assets and the Selection of Risky. Review of Economics, 13-37.

Nayan, M. A. (2013). Research Report: Cement Sector of Bangladesh-Update. Dhaka: IDLC Investment Ltd.

Rahman, M., Baten, A., Uddin, B., \& Zubayer, M. (2006). Fama-Frenchs CAPM: An empirical investigation on DSE. Journal of Applied Sciences, 2297-2301.

Sharpe, W. (1964). Capital Asset Prices: A Theory of Market Equilibrium. Journal of Finance, 19, 425-442.

\section{Appendix}

Regression Results (ANOVA table)

11.1 Aramit Cement Multiple Regression Summery Output

\begin{tabular}{lllll}
\hline Regression Statistics & & & \\
\hline Multiple R & 0.840497074 & & \\
R Square & 0.706435331 & & \\
Adjusted R Square & 0.706032083 & & \\
Standard Error & 0.022059672 & & & \\
Observations & 2663 & & & \\
ANOVA & & & Significance F \\
\hline
\end{tabular}




\begin{tabular}{lllllllll}
\hline Regression & 3 & 2.557521877 & 0.852507292 & 1751.862451 & 0.00 & & & \\
Residual & 2659 & 1.06279801 & 0.000486629 & & & & \\
Total & 2662 & 3.620319887 & & & & & & \\
& Coefficients & Standard Error & t Stat & P-value & Lower 95\% & Upper 95\% & Lower 95.0\% & Upper 95.0\% \\
& 0.000580285 & 0.000471887 & 1.229712099 & 0.218937388 & -0.000345109 & 0.00150568 & -0.000345109 & 0.00150568 \\
Intercept & 0.791457363 & 0.028264858 & 28.00146284 & $1.099 \mathrm{E}-147$ & 0.736028541 & 0.846886184 & 0.736028541 & 0.846886184 \\
Mkt-Rf & 0.765303789 & 0.018329295 & 41.75304046 & $1.3169 \mathrm{E}-280$ & 0.729359111 & 0.801248467 & 0.729359111 & 0.801248467 \\
SMB & -0.652135583 & 0.020703675 & -31.498543 & $7.4343 \mathrm{E}-180$ & -0.69273654 & -0.611534626 & -0.69273654 & -0.611534626 \\
HML & & & & & & & &
\end{tabular}

11.2 Confidence Cement Multiple Regression Summery Output

\begin{tabular}{|c|c|c|c|c|c|c|c|c|}
\hline \multicolumn{8}{|l|}{ Regression Statistics } & \\
\hline Multiple R & 0.729616356 & & & & & & & \\
\hline R Square & 0.532340027 & & & & & & & \\
\hline Adjusted R Square & 0.531697637 & & & & & & & \\
\hline Standard Error & 0.021134191 & & & & & & & \\
\hline Observations & 2663 & & & & & & & \\
\hline \multicolumn{9}{|l|}{ ANOVA } \\
\hline & $d f$ & SS & $M S$ & $F$ & Significance F & & & \\
\hline Regression & 3 & 1.110408599 & 0.3701362 & 828.6865709 & 0 & & & \\
\hline Residual & 2659 & 0.97549241 & 0.000446654 & & & & & \\
\hline \multirow[t]{2}{*}{ Total } & 2662 & 2.085901008 & & & & & & \\
\hline & Coefficients & Standard Error & $t$ Stat & $P$-value & Lower $95 \%$ & Upper $95 \%$ & Lower $95.0 \%$ & Upper $95.0 \%$ \\
\hline Intercept & 0.000412551 & 0.00045209 & 0.912543211 & 0.361583551 & -0.000474019 & 0.001299122 & -0.000474019 & 0.001299122 \\
\hline Mkt-Rf & 1.011314788 & 0.027079048 & 37.34676366 & $1.6662 \mathrm{E}-236$ & 0.958211401 & 1.064418175 & 0.958211401 & 1.064418175 \\
\hline SMB & 0.355752367 & 0.017560316 & 20.2588813 & $9.18522 \mathrm{E}-84$ & 0.321315695 & 0.390189039 & 0.321315695 & 0.390189039 \\
\hline HML & 0.54910253 & 0.019835083 & 27.6834002 & 7.6396E-145 & 0.510204925 & 0.588000134 & 0.510204925 & 0.588000134 \\
\hline
\end{tabular}

\subsection{Heidelberg Cement Multiple Regression Summery Output}

\begin{tabular}{|c|c|c|c|c|c|c|c|c|}
\hline \multicolumn{8}{|l|}{ Regression Statistics } & \\
\hline Multiple R & 0.605309974 & & & & & & & \\
\hline R Square & 0.366400164 & & & & & & & \\
\hline Adjusted R Square & 0.365529835 & & & & & & & \\
\hline Standard Error & 0.019669574 & & & & & & & \\
\hline Observations & 2663 & & & & & & & \\
\hline \multicolumn{9}{|l|}{ ANOVA } \\
\hline & $d f$ & SS & MS & $F$ & Significance F & & & \\
\hline Regression & 3 & 0.488633394 & 0.162877798 & 420.9901967 & $8.6313 \mathrm{E}-216$ & & & \\
\hline Residual & 2659 & 0.844972433 & 0.000386892 & & & & & \\
\hline \multirow[t]{2}{*}{ Total } & 2662 & 1.333605827 & & & & & & \\
\hline & Coefficients & Standard Error & $t$ Stat & $P$-value & Lower 95\% & Upper $95 \%$ & Lower $95.0 \%$ & Upper $95.0 \%$ \\
\hline Intercept & 0.00039252 & 0.00042076 & 0.932883717 & 0.350983129 & -0.000432611 & 0.00121765 & -0.000432611 & 0.00121765 \\
\hline Mkt-Rf & 0.774272763 & 0.025202447 & 30.7221266 & $1.4043 \mathrm{E}-172$ & 0.724849485 & 0.823696041 & 0.724849485 & 0.823696041 \\
\hline SMB & -0.118144321 & 0.016343372 & -7.228882921 & $6.70244 \mathrm{E}-13$ & -0.150194503 & -0.086094139 & -0.150194503 & -0.086094139 \\
\hline HML & 0.238012182 & 0.018460495 & 12.89305542 & $1.0377 \mathrm{E}-36$ & 0.201810214 & 0.27421415 & 0.201810214 & 0.27421415 \\
\hline
\end{tabular}

\subsection{Lafarge Surma Cement Multiple Regression Summery Output}

\begin{tabular}{ll}
\hline Regression Statistics & \\
\hline Multiple R & 0.786136843 \\
\hline
\end{tabular}




\begin{tabular}{|c|c|c|c|c|c|c|c|c|}
\hline R Square & 0.618011137 & & & & & & & \\
\hline Adjusted R Square & 0.617486427 & & & & & & & \\
\hline Standard Error & 0.01730538 & & & & & & & \\
\hline Observations & 2663 & & & & & & & \\
\hline \multicolumn{9}{|l|}{ ANOVA } \\
\hline & $d f$ & SS & $M S$ & $F$ & Significance F & & & \\
\hline Regression & 3 & 1.058182376 & 0.352727459 & 1177.814723 & 0 & & & \\
\hline Residual & 2659 & 0.654055986 & 0.000299476 & & & & & \\
\hline \multirow[t]{2}{*}{ Total } & 2662 & 1.712238361 & & & & & & \\
\hline & Coefficients & Standard Error & t Stat & $P$-value & Lower $95 \%$ & Upper $95 \%$ & Lower $95.0 \%$ & Upper $95.0 \%$ \\
\hline Intercept & 0.000224786 & 0.000370186 & 0.607224014 & 0.543765381 & -0.000501168 & 0.00095074 & -0.000501168 & 0.00095074 \\
\hline Mkt-Rf & 0.994130188 & 0.022173227 & 44.83470973 & 0 & 0.950647364 & 1.037613012 & 0.950647364 & 1.037613012 \\
\hline SMB & -0.527695744 & 0.014378973 & -36.6991274 & $4.2089 \mathrm{E}-230$ & -0.555893639 & -0.499497848 & -0.555893639 & -0.499497848 \\
\hline HML & -0.560749705 & 0.016241627 & -34.52546415 & $8.0408 \mathrm{E}-209$ & -0.59260036 & -0.52889905 & -0.59260036 & -0.52889905 \\
\hline
\end{tabular}

\subsection{Meghna Cement Multiple Regression Summery Output}

\begin{tabular}{|c|c|c|c|c|c|c|c|c|}
\hline \multicolumn{9}{|l|}{ Regression Statistics } \\
\hline Multiple R & 0.724036927 & & & & & & & \\
\hline R Square & 0.524229471 & & & & & & & \\
\hline Adjusted R Square & 0.52357594 & & & & & & & \\
\hline Standard Error & 0.022479546 & & & & & & & \\
\hline Observations & 2663 & & & & & & & \\
\hline \multicolumn{9}{|l|}{ ANOVA } \\
\hline & $d f$ & SS & $M S$ & $F$ & Significance $F$ & & & \\
\hline Regression & 3 & 1.216050522 & 0.405350174 & 802.1494234 & 0 & & & \\
\hline Residual & 2659 & 1.103640736 & 0.00050533 & & & & & \\
\hline \multirow[t]{2}{*}{ Total } & 2662 & 2.319691259 & & & & & & \\
\hline & Coefficients & Standard Error & $t$ Stat & $P$-value & Lower 95\% & Upper $95 \%$ & Lower $95.0 \%$ & Upper $95.0 \%$ \\
\hline Intercept & 3.70204E-05 & 0.000480869 & 0.076986528 & 0.938641314 & -0.000905988 & 0.000980028 & -0.000905988 & 0.000980028 \\
\hline Mkt-Rf & 0.976945588 & 0.028802839 & 33.91837813 & $6.0743 \mathrm{E}-203$ & 0.920461758 & 1.033429418 & 0.920461758 & 1.033429418 \\
\hline SMB & 0.588856146 & 0.018678167 & 31.52644198 & $4.0598 \mathrm{E}-180$ & 0.552227312 & 0.625484979 & 0.552227312 & 0.625484979 \\
\hline HML & 0.32939806 & 0.02109774 & 15.61295506 & $3.53153 \mathrm{E}-52$ & 0.288024321 & 0.370771798 & 0.288024321 & 0.370771798 \\
\hline
\end{tabular}

11.6 Aramit Cement Simple Linear Regression Summery Output

\begin{tabular}{|c|c|c|c|c|c|c|c|c|}
\hline \multicolumn{9}{|l|}{ Regression Statistics } \\
\hline Multiple R & \multicolumn{8}{|l|}{0.362218804} \\
\hline R Square & \multicolumn{8}{|l|}{0.131202462} \\
\hline Adjusted R Square & \multicolumn{8}{|l|}{0.130805025} \\
\hline Standard Error & \multicolumn{8}{|l|}{0.03793217} \\
\hline Observations & \multicolumn{8}{|l|}{2663} \\
\hline \multicolumn{9}{|l|}{ ANOVA } \\
\hline & $d f$ & SS & $M S$ & $F$ & Significance $F$ & & & \\
\hline Regression & 1 & 0.474994883 & 0.474994883 & 330.1213107 & $8.12455 \mathrm{E}-69$ & & & \\
\hline Residual & 2661 & 3.145325005 & 0.001438849 & & & & & \\
\hline \multirow[t]{2}{*}{ Total } & 2662 & 3.620319887 & & & & & & \\
\hline & Coefficients & Standard Error & $t$ Stat & P-value & Lower $95 \%$ & Upper $95 \%$ & Lower $95.0 \%$ & Upper $95.0 \%$ \\
\hline Intercept & 0.000964551 & 0.000811311 & 1.188879464 & 0.234616232 & -0.00062647 & 0.002555573 & -0.00062647 & 0.002555573 \\
\hline Mkt-Rf & 0.878502212 & 0.048351069 & 18.16924079 & $8.12455 \mathrm{E}-69$ & 0.783683359 & 0.973321066 & 0.783683359 & 0.973321066 \\
\hline \multicolumn{9}{|c|}{7 Confidence Cement Simple Linear Regression Summery Output } \\
\hline \multicolumn{9}{|l|}{ Regression Statistics } \\
\hline Multiple R & 0.585700179 & & & & & & & \\
\hline R Square & 0.343044699 & & & & & & & \\
\hline Adjusted R Square & 0.342744171 & & & & & & & \\
\hline Standard Error & 0.025037426 & & & & & & & \\
\hline
\end{tabular}




\begin{tabular}{|c|c|c|c|c|c|c|c|c|}
\hline Observations & 2663 & & & & & & & \\
\hline \multicolumn{9}{|l|}{ ANOVA } \\
\hline & $d f$ & SS & $M S$ & $F$ & Significance F & & & \\
\hline Regression & 1 & 0.715557284 & 0.715557284 & 1141.471439 & $1.0732 \mathrm{E}-201$ & & & \\
\hline Residual & 2661 & 1.370343724 & 0.000626873 & & & & & \\
\hline \multirow[t]{2}{*}{ Total } & 2662 & 2.085901008 & & & & & & \\
\hline & Coefficients & Standard Error & $t$ Stat & $P$-value & Lower 95\% & Upper 95\% & Lower $95.0 \%$ & Upper $95.0 \%$ \\
\hline Intercept & 0.00053574 & 0.000535512 & 1.000424732 & 0.317215731 & -0.000514427 & 0.001585906 & -0.000514427 & 0.001585906 \\
\hline Mkt-Rf & 1.078252808 & 0.031914502 & 33.78566914 & $1.0732 \mathrm{E}-201$ & 1.01566688 & 1.140838735 & 1.01566688 & 1.140838735 \\
\hline
\end{tabular}

11.8 Heidelberg Cement Simple Linear Regression Summery Output

\begin{tabular}{|c|c|c|c|c|c|c|c|c|}
\hline \multicolumn{9}{|l|}{ Regression Statistics } \\
\hline Multiple R & 0.519764909 & & & & & & & \\
\hline R Square & 0.270155561 & & & & & & & \\
\hline Adjusted R Square & 0.269821689 & & & & & & & \\
\hline Standard Error & 0.021101038 & & & & & & & \\
\hline Observations & 2663 & & & & & & & \\
\hline \multicolumn{9}{|l|}{ ANOVA } \\
\hline & $d f$ & SS & $M S$ & $F$ & Significance $F$ & & & \\
\hline Regression & 1 & 0.36028103 & 0.36028103 & 809.1588079 & $1.0628 \mathrm{E}-151$ & & & \\
\hline Residual & 2661 & 0.973324797 & 0.000445254 & & & & & \\
\hline \multirow[t]{2}{*}{ Total } & 2662 & 1.333605827 & & & & & & \\
\hline & Coefficients & Standard Error & $t$ Stat & $P$-value & Lower 95\% & Upper $95 \%$ & Lower $95.0 \%$ & Upper $95.0 \%$ \\
\hline Intercept & 0.000324265 & 0.000451319 & 0.718482163 & 0.472536827 & -0.000560794 & 0.001209324 & -0.000560794 & 0.001209324 \\
\hline Mkt-Rf & 0.765101568 & 0.026896899 & 28.44571686 & $1.0628 \mathrm{E}-151$ & 0.712355411 & 0.817847726 & 0.712355411 & 0.817847726 \\
\hline
\end{tabular}

\subsection{Lafarge Surma Cement Simple Linear Regression Summery Output}

\begin{tabular}{|c|c|c|c|c|c|c|c|c|}
\hline \multicolumn{9}{|l|}{ Regression Statistics } \\
\hline Multiple R & \multicolumn{8}{|l|}{0.541219678} \\
\hline R Square & \multicolumn{8}{|l|}{0.29291874} \\
\hline Adjusted R Square & \multicolumn{8}{|l|}{0.292595281} \\
\hline Standard Error & \multicolumn{8}{|l|}{0.02353378} \\
\hline Observations & \multicolumn{8}{|l|}{2663} \\
\hline \multicolumn{9}{|l|}{ ANOVA } \\
\hline & $d f$ & $S S$ & $M S$ & $F$ & Significance $F$ & & & \\
\hline Regression & 1 & 0.501546703 & 0.501546703 & 905.5824302 & $9.2937 \mathrm{E}-167$ & & & \\
\hline Residual & 2661 & 1.210691658 & 0.000553839 & & & & & \\
\hline \multirow[t]{2}{*}{ Total } & 2662 & 1.712238361 & & & & & & \\
\hline & Coefficients & Standard Error & $t$ Stat & $P$-value & Lower 95\% & Upper $95 \%$ & Lower $95.0 \%$ & Upper $95.0 \%$ \\
\hline Intercept & $2.55518 \mathrm{E}-05$ & 0.000503352 & 0.050763233 & 0.959518827 & -0.000961546 & 0.001012649 & -0.000961546 & 0.001012649 \\
\hline Mkt-Rf & 0.90272212 & 0.029997847 & 30.09289667 & $9.2937 \mathrm{E}-167$ & 0.843894848 & 0.961549392 & 0.843894848 & 0.961549392 \\
\hline
\end{tabular}

\subsection{Meghna Cement Simple Linear Regression Summery Output}

\begin{tabular}{|c|c|c|c|c|c|}
\hline \multicolumn{6}{|l|}{ Regression Statistics } \\
\hline Multiple R & 0.551017728 & & & & \\
\hline R Square & 0.303620537 & & & & \\
\hline Adjusted R Square & 0.303301973 & & & & \\
\hline Standard Error & 0.027183977 & & & & \\
\hline Observations & 2663 & & & & \\
\hline \multicolumn{6}{|l|}{ ANOVA } \\
\hline & $d f$ & SS & $M S$ & $F$ & Significance $F$ \\
\hline Regression & 1 & 0.704305905 & 0.704305905 & 953.0931457 & $5.2611 \mathrm{E}-174$ \\
\hline Residual & 2661 & 1.615385354 & 0.000738969 & & \\
\hline
\end{tabular}




\begin{tabular}{lllllllll}
\hline Total & 2662 & 2.319691259 & & & & & \\
& Coefficients & Standard Error & $t$ Stat & P-value & Lower 95\% & Upper 95\% & Lower 95.0\% & Upper 95.0\% \\
Intercept & 0.000278623 & 0.000581424 & 0.479207974 & 0.631838615 & -0.000861578 & 0.001418824 & -0.000861578 & 0.001418824 \\
Mkt-Rf & 1.069742029 & 0.03465065 & 30.87220669 & $5.2611 \mathrm{E}-174$ & 1.001790379 & 1.137693679 & 1.001790379 & 1.137693679 \\
\hline
\end{tabular}

\section{Copyrights}

Copyright for this article is retained by the author(s), with first publication rights granted to the journal.

This is an open-access article distributed under the terms and conditions of the Creative Commons Attribution license (http://creativecommons.org/licenses/by/4.0/). 